\title{
Revizuirea procedurii de negociere a aderării noilor state membre - între limbajul diplomatic și provocările concrete -
}

\author{
Lect.univ.dr. Mihaela-Augustina Dumitrașcu \\ Drd. Dragoș - Adrian Bantaș \\ Facultatea de Drept, Universitatea din București
}

\begin{abstract}
Aderarea noilor state membre la Uniunea Europeană reprezintă un proces preponderent politic și diplomatic, a cărui consacrare juridică în dreptul primar al Uniunii Europene vizează cu preponderență coordonatele sale generale, aspectele de detaliu căzând in principal în responsabilitatea practicii instituționale și diplomatice a instituțiilor unionale și a statelor membre. Deși se poate considera că a funcționat mulțumitor până în prezent, suprapunerea intereselor naționale ale statelor cu o reglementare laxă în dreptul unional, $\hat{\imath} n$ contextul provocărilor ridicate de contextul politic și economic internațional și al complexității problemelor legate de statele candidate la aderare din regiunea Balcanilor, a generat și situații lipsite de predictibilitate şi având un potențial ridicat de a genera resentimente în rândul acetor state. Pentru prevenirea, în viitor, a reapariției unor astfel de situații, Comisia a elaborat o serie de propuneri de revizuire a procedurii de negociere a aderării noilor state membre, care fac obiectul prezentului demers.
\end{abstract}

Cuvinte cheie: revizuire; procedură; aderare; state membre; Comisia Europeană.

Review of the procedure for negotiating the accession to the eu of new member states - diplomatic language and concrete challenges

\begin{abstract}
The accession of the new Member States to the European Union is a predominantly political and diplomatic process, the legal enshrinement of which in the European Union's primary law mainly concerns its general coordinates, its practical details falling mainly on the institutional and diplomatic practice of the EU and Member States. Although the overlapping of the national interests with lax regulation in Union law have been considered to have worked satisfactorily so far, they have also generated unpredictable situations in the context of the challenges posed by the international political and economic context and by the complexity of the issues related to the candidate countries in the Balkans, therefore having a high potential to generate resentment among these states. In order to prevent such situations from recurring in the future, the Commission has drawn up a number of proposals to revise the procedure for negotiating the accession of the new Member States, which are the subject of this research.
\end{abstract}

Keywords: review; procedure; accession; member states; The European Commission.

A discuta despre aderarea de noi state la Uniunea Europeană în aceste momente, când atenția decidenților și a analiștilor, deopotrivă, este îndreptată fie spre pandemia care amenință nu doar Uniunea Europeană, ci întreaga lume, astfel cum o cunoaștem noi, cel puțin, fie, în ceea ce, sub impresia provocată de răspândirea noului coronavirus, pare deja un eveniment îndepărtat (și ne referim aici la celebra retragere a Marii Britanii din Uniune), poate apărea, într-un caz fericit, ca o naivitate, sau, într-unul mai puțin fericit, ca un exercițiu intelectual lipsit, în mod coștient, de orice utilitate.

Cu toate acestea, îndrăznim să opinăm că nu este nici una, nici cealaltă, și că tocmai în aceste momente de criză este necesar și oportun să vorbim atât despre dimensiunea calitativă (respectiv adâncirea integrării, în cazul statelor care dețin deja calitatea de membru al Uniunii Europene), cât și despre dimensiunea cantitativă a fenomenului unional. 
Aceasta deoarece atât analiza evolutivă, istorică, a dezvoltării comunitare și unionale ${ }^{1}$, cât și doctrina de specialitate scot în evidență faptul că pe întreaga durată a existenței acestora, „Comunităţile Europene s-au confruntat cu situații de criză [însă de fiecare dată acestea] au fost soluționate cu ajutorul reflecțiilor privind modalitățile de depășire a acestora"2. Mai mult chiar, crizele de până acum și modalitățile identificate pentru soluționarea acestora au dus, aproape de fiecare dată, la aprofundarea unor mecanisme până atunci considerate inaplicabile altor entități decât statele membre. Și totuși, la aproape 70 ani de la primele astfel de crize și de la primele momente în care i s-a prezis sfârșitul, Uniunea nu doar că există, ci justifică faptul de a fi considerată de o parte a literaturii de specialitate $^{3}$ drept o veritabilă ordine juridică de natură constituţională. Iar retragerea Marii Britanii nu reprezintă, opinăm noi, o excepție de la această regulă, chiar dacă justețea acestei afirmații este de așteptat să se releve doar într-un orizont mediu sau lung de timp.

Din seria modalităţilor de depășire a crizei (în special de încredere) generată de prima retragere a unui stat din Uniune ${ }^{4}$ poate face parte și dobândirea calității de stat membru de către o serie de state actualmente candidate, în special din regiunea Balcanilor de Vest, ceea ce ar aduce mai aproape dezideratul unei suprapuneri perfecte a Uniunii peste noțiunea de continent european, excluzând (cel puțin deocamdată) anumite state ex-sovietice care nu și-au manifestat intenția de a dobândi statutul de stat membru.

De altfel, procesul de asocierea statelor în organizații internaționale (în special regionale) și chiar supranaționale este o caracteristică a mediului internațional de după cel deal doilea Război Mondial și, date fiind forța economică și de negociere, precum și influența scăzută pe care statele europene, considerate în mod individual, o pot avea într-o lume dominată de o superputere (SUA) și două mari puteri (China și Rusia), nu considerăm că ar trebui să ne așteptăm la o inversare ci, din contră, la o intensificare a acestei tendințe, eventualele exemple contrare constituind excepții pe care evenimentele viitoare le vor considera drept reușite ale unor actori, respectiv eșecuri ale celor care le-au efectuat.

În acest sens, suntem de acord cu afirmaţiile doctrinei de specialitate, conform căreia „dezvoltarea relațiilor internaționale dintre state s-a manifestat, după cel de-al Doilea Război Mondial, prin crearea unor importante asocieri în vederea atingerii unor obiective generale comune precum menținerea păcii și cooperarea internațională sau a unor obiective specifice de natură militarăa, economico-comercială sau științifico-culturală; acestea au devenit organizații internaționale interguvernamentale, respectiv subiecte distincte de drept internațional public dotate cu personalitate juridică, dobândind un rol major în plan internațional"s.

De altfel, procesul de aderare a statelor din Balcanii de Vest se află în desfășurare de o bună perioadă de timp, interval în care nu puține au fost progresele obținute. Spre exemplu, în ordinea alfabetică a denumirilor statelor în cauză, Albania beneficiază de statutul de stat candidat din anul 2014, Muntenegru din 2010, Serbia din 2012, iar Turcia din 1999, în timp ce Bosnia și Herțegovina, respectiv Kosovo sunt state potențial candidate. Din această enumerare lipsește, însă, Macedonia de Nord, dar numai pentru că situația sa specială constituie obiectul acestui demers.

\footnotetext{
${ }^{1}$ La care recurgem în mod frecvent, nu spre a încerca răbdarea studenților, ci pentru că orice fenomen prezintă o serie de cauze pe care nu le putem identifica decât în parcursul său de până la momentul analizei și în lipsa cărora nu ne putem crea o impresie corectă despre viitorul său.

${ }^{2}$ Augustin Fuerea, Manualul Uniunii Europene, Ediția a V-a revăzută și adăugită după Tratatul de la Lisabona, Editura Universul Juridic, București, 2011, p. 20.

${ }^{3}$ A se vedea Robert Schutze - European Constitutional Law (Cambridge University Press, 2012) și nu numai.

${ }^{4}$ Groenlanda neîncadrându-se în noțiunea de stat.

${ }^{5}$ Oana-Mihaela Salomia, Augustin Mihalache, Principiul egalității statelor membre în cadrul Uniunii Europene, Revista "Dreptul", nr. 1/2016, pp. 166-174.
} 
Astfel, în ceea ce privește, pe scurt, situația Macedoniei de Nord (cunoscută până la soluționarea diferendului cu Grecia referitor la denumirea sa, drept Fosta Republică Iugoslavă a Macedoniei), menționăm că acesteia i s-a recunoscut statutul de potențial candidat cu ocazia reuniunii Consiliului European de la Salonic, din 2003. Ulterior, în anul 2004, Macedonia a fost primul stat din regiunea Balcanilor de Vest care a semnat un Acord de Stabilizare și Asociere, formulându-și cererea de aderare în luna martie a aceluiași an, pentru ca, în 2005, Consiliul să îi acorde statutul de stat candidat ${ }^{6}$.

În continuare, Comisia a recomandat, începând cu anul 2009, demararea negocierilor de aderare, recomandările din anii 2015 și 2016 condiționând acest demers de respectarea Acordului de la Pržino și de obținerea unor progrese semnificative în direcția implementării unui pachet de reforme considerate de imediată urgență. Ținând cont de progresele obținute și de respectarea condițiilor impuse de Consiliu în iunie 2018, Comisia și-a reiterat recomandarea de demarare necondiționată a negocierilor de aderare în anul $2019^{7}$. Cu toate acestea, în luna octombrie a anului 2019, reprezentantul Franţei s-a opus, în cadrul Consiliului, demarării negocierilor de aderare cu Macedonia de Nord și Albania, motivându-și refuzul prin necesitatea efectării unor reforme suplimentare ${ }^{8}$.

În mod evident, acest refuz a generat o întreagă serie de reacții, în majoritate negative, atât din partea observatorilor din statele membre, cât și a celor din Macedonia și Albania, respectiv Balcanii de Vest în ansamblul lor, axate în mod preponderent pe aparenta lipsă de predictibilitate și de obiectivitate a procedurii de aderare în ansamblul ei, ceea ce a determinat Comisia să demareze o serie de consultări în scopul revizuirii acestei proceduri. Despre aceste propuneri vom discuta în cele ce urmează.

Până atunci, însă, ne vom referi pe scurt la câteva aspecte privitoare la cadrul general al procedurii de aderare a noilor state la Uniune, astfel cum este acesta reglementat de izvoarele de drept primar unional și cum se prezenta înainte de revizuirea procedurii de aderare prin documentele pe care le vom prezenta.

Nedorind, totuși, să insistăm asupra unui subiect pe care 1-am mai abordat, abuzând, astfel, de răbdarea cititorului, ne vom mărgini să afirmăm că, în prezent, sediul principal al materiei în ceea ce privește aderarea la Uniunea Europeană este reprezentat de art. 49 TUE$^{9}$, care, la rândul său, face trimitere la valorile pe care se întemeiază Uniunea, consacrate în art. 2 TUE$^{10}$ și la criteriile cuprinse în Concluziile Consiliului European de la Copenhaga, din 1993 și revizuite cu ocazia reuniunii Consiliului European de la Madrid, desfăşurat doi ani mai târziu.

În ceea ce privește procedura propriu-zisă de negociere, iniţial, aceasta nu era consacrată la nivel de drept primar, bazându-se preponderent pe practica urmată de Comisie și pe colaborarea interinstituțională dintre aceasta, Consiliu și Parlament. În linii generale, însă,

\footnotetext{
6 *** North Macedonia, ec.europa.eu, 15.04.2020, accesat 24.05.2020.

7 *** North Macedonia, ec.europa.eu, 15.04.2020, accesat 24.05.2020.

8 Gabriela Baczynska, France opposes EU membership talks with North Macedonia, Albania: diplomats, www.reuters.com, 10.10.2019, accesat 24.05.2020.

9 „Orice stat european care respectă valorile prevăzute la articolul 2 și care se angajează să le promoveze poate solicita să devină membru al Uniunii. Parlamentul European și parlamentele naționale sunt informate cu privire la această cerere. Statul solicitant adresează cererea sa Consiliului, care se pronunță în unanimitate după consultarea Comisiei și după aprobarea Parlamentului European, care se pronunță cu majoritatea membrilor din care este constituit. Criteriile de eligibilitate aprobate de Consiliul European se iau in considerare. Condițiile admiterii și adaptările impuse de aceasta tratatelor pe care se întemeiază Uniunea fac obiectul unui acord între statele membre și statul solicitant. Acest acord se supune ratificării de către toate statele contractante, in conformitate cu normele lor constituționale”.

10 „Uniunea se întemeiază pe valorile respectării demnității umane, libertății, democrației, egalității, statului de drept, precum și pe respectarea drepturilor omului, inclusiv a drepturilor persoanelorcare aparțin minorităților. Aceste valori sunt comune statelor membre într-o societate caracterizată prin pluralism, nediscriminare, toleranță, justiție, solidaritate și egalitate între femei și bărbați”."
} 
aceasta cuprindea semnarea unui Acord de asociere sau a unui Acord european de asociere ${ }^{11}$ (în cazul României, spre exemplu, fiind vorba despre un Acord european instituind o asociere intre CE/statele membre, pe de o parte, și România, pe de altă parte), înaintarea de către statul în cauză a unei Cereri de aderare, conferirea, prin Decizie a Consiliului, a statutului de stat candidat și demararea, prin Decizie a Consiliului, a negocierilor dintre UE și statul în cauză, desfăşurarea propriu-zisă a negocierilor, încheierea acestora şi redactarea, respectiv adoptarea Tratatului de Aderare, semnarea și ratificarea acestuia de catre statele membre și statul candidat și, în final, aderarea propriu-zisă ${ }^{12}$.

Revenind acum la desfășurarea propriu-zisă a negocierilor și noua metodologie privitoare la acestea, Comisia a adoptat actul în cauză în data de 5 februarie 2020, ocazie cu care domnul Olivér Várhelyi, membru al Comisiei gestionând portofoliul Vecinătății și Extinderii, a susținut o conferință de presă în cadrul căreia a prezentat principalele coordonate ale noii proceduri de negociere a aderării statelor candidate.

Conform domniei sale, obiectivul acestei propuneri este acela de a restabili credibilitatea perspectivei dobândirii calităţii de stat membru pentru statele din regiunea Balcanilor de Vest și exprimarea cu claritate a faptului că, pentru Comisie și Uniune în ansamblul său, edificarea unui climat de stabilitate, pace și prosperitate în această regiune reprezintă o prioritate. În această idee, extinderea Uniunii reprezintă un proiect politic cheie, desfăşurat în conformitate cu o abordare bazată pe merite și în condițiile menținerii perspectivei de a dobândi calitatea de stat membru pentru toate statele din regiune. Practic, conform aceleiași declarații, acest demers reprezintă o adevărată investiție geostrategică, necesar a fi efectuată, dar pentru a cărei realizare este nevoie ca statele candidate să își ofere întregul lor concurs. Exact pentru atingerea acestor obiective, Comisia a reanalizat evenimentele politice petrecute în luna octombrie a anului 2019, care au dus la blocarea (temporară) a negocierilor de aderare pentru țările în cauză ${ }^{13}$.

În acest context, conform aceleiași declarații, Comisia a depus toate diligențele pentru a identifica și combate cauzele acestui eșec, fără ca prin aceasta să accepte eventuale compromisuri în ceea ce privește principiile care stau la baza procesului de extindere. Din acest demers a rezultat propunerea despre care discutăm astăzi, de revizuire a procedurii de aderare, şi care, conform declarației domnului ... se bazează pe patru principii fundamentale, și anume, credibilitatea, predictibilitatea, dinamismul și un rol crescut al supervizării politice $^{14}$.

Le vom analiza, pe rând, în ceea ce urmează.

Astfel, în ceea ce privește principiul credibilității, Comisia dorește, prin intermediul acestuia să aducă un plus de claritate în ceea ce privește obiectivele sale, ceea ce pretinde de la statele candidate și ce oferă în cazul în care acestea se conformează, ceea ce ar trebui să contribuie la restabilirea acelei încrederi profunde și reciproce nu doar între statele din Balcanii de Vest și Statele Membre, ci și între societățile acestora ${ }^{15}$.

\footnotetext{
${ }^{11}$ Diferența dintre acestea fiind dată de faptul că ultimul cuprinde și perspectiva de aderare a statului semnatar, în timp ce primul cuprinde preponderent aspecte economice, însă în funcție de evoluția evenimentelor politice, nimic nu împiedica faptul ca un Acord inițial de asociere să fie urmat de un Acord european de asociere, la fel cum aceste aspecte pot cunoaște variații suplimentare în funcție de situația fiecărui stat.

12 Augustina Dumitrașcu, Roxana-Mariana Popescu, Dreptul Uniunii Europene: sinteze și aplicații, ediția a II-a revăzută și adăugită , Editura Universul Juridic, București, 2015, pp. 173-175.

13 *** Remarks by Commissioner Olivér Várhelyi at the press conference on the revised enlargement methodology, 05.02.2020, accesat 24.05.2020.

14 *** Remarks by Commissioner Olivér Várhelyi at the press conference on the revised enlargement methodology, 05.02.2020, accesat 24.05.2020.

15 *** Remarks by Commissioner Olivér Várhelyi at the press conference on the revised enlargement methodology, 05.02.2020, accesat 24.05.2020.
} 
În această idee, proiectul subliniază necesitatea ca procesul de aderare să fie bazat pe încredere reciprocă și angajamente clare atât din partea Uniunii, cât și a Statelor Membre. Acest climat de încredere trebuie întârit prin plasarea unui accent mai puternic asupra reformelor fundamentale, începând cu domnia legii, funcționarea instituțiilor democratice, continuând cu administrațiile și sectoarele economice ale statelor candidate. În continuare, atunci când un stat candidat ajunge să îndeplinească criteriile menționate, statele membre se obligă (shall) să consimtă ca procesul de negociere să treacă într-o fază superioară, în respectul unei abordări bazate pe merit ${ }^{16}$.

Prin documentul citat, Uniunea evidențiază faptul că în situația în care reformele cerute sunt urmărite constant și eficient, aceasta va putea să își îndeplinească, la rândul său, partea sa de angajament, în condițiile continuării abordării bazate pe merit. Dar pentru eficiența unei astfel de abordări se impune o evaluare periodică a progreselor obținute. ${ }^{17}$

Pentru întărirea credibilităţii este necesar, în viziunea Comisiei, un accent mai puternic asupra reformelor fundamentale esențiale pentru succesul parcursului european. Din acest motiv, reformele în cauză vor ocupa un loc central în negocierile pentru aderare. Mai exact, capitolele de negociere cuprinzând aceste aspecte vor fi deschise primele și închise ultimele, iar parcursul lor va determina ritmul general al negocierilor.

Acesta ar urma să fie jalonat de următoarele instrumente cu rol de reper în ceea ce privește organizarea generală a procesului de negociere: o foaie de parcurs referitoare la capitolele de negociere legate de domnia legii, echivalentă cu planurile anterioare de ațiune, care va constitui un prim și general element de referință, și niveluri intermediare ce urmează să fie stabilite (în descursul procesului de negociere, deducem), de menționat fiind faptul că nici un capitol nu va fi închis provizoriu până nu vor fi atinse aceste niveluri intermediare; o foaie de parcurs privitoare la funcționarea instituțiilor democratice și la reforma administrației publice; precum și o legătură mai puternică cu procesul de reformă în domeniul economic, pentru a veni în sprijinul statelor candidate în ceea ce privește îndeplinirea criteriului economic de aderare ${ }^{18}$.

Procedând mai departe la analiza următorului element, întărirea controlului politic ${ }^{19}$ asupra procesului de aderare, în remarcile Comisarului Várhelyi, acesta preciza că ceea ce se dorește la nivelul Comisiei este consolidarea dialogului constant cu statele din regiune, concomitent cu aprofundarea procesului de reflecție politică asupra progreselor acestora în direcția aderării. Prin urmare, Comisia adresează șefilor de state și de guverne din UE invitaţia de a susține dezbateri cel puțin anuale privitoare la progresele statelor candidate, pe baza a ceea ce urma să se hotărască cu ocazia Reuniunii Consiliului European de la Zagreb ${ }^{20}$.

Detalii suplimentare sunt oferite de propunerea Comisiei, care subliniază că desfăşurarea procesului de aderare face necesar un mai puternic control politic și un angajament profund din partea statelor membre, la cel mai înalt nivel. Din acest motiv, Comisia propune identificarea de oportunităţi suplimentare de dialog politic la nivel înalt, prin reuniuni constante în formatul UE-Balcanii de Vest, precum și prin intensificarea contactelor interministeriale. Mai mult, Comisia consideră necesară și o implicare suplimentară și sistematică a Statelor Membre în monitorizarea și supervizarea procesului. În această idee,

\footnotetext{
${ }^{16}$ Communication from the Commission to the Euroepan Parliament, the Council, the Euroepan Economic and Social Committee and the Committee of the Regions: Enhancing the accession process - A credible EU perspective for the Western Balkans, COM(2020) 57 final, Brussels, 5.2.2020.

17 *** Remarks by Commissioner Olivér Várhelyi at the press conference on the revised enlargement methodology, 05.02.2020, accesat 24.05.2020.

${ }^{18}$ A se vedea Criteriile de la Copenhaga, menționate mai sus.

19 Precizăm că prin această exprimare nu ne referim la conceptul de control politic din dreptul constituțional, ci la echivalentul românesc al formulării ,,political steer” din Comunicarea citată a Comisiei.

20 *** Remarks by Commissioner Olivér Várhelyi at the press conference on the revised enlargement methodology, 05.02.2020, accesat 24.05.2020.
} 
Comisia propune ca toate organismele din cadrul Acordurilor de Stabilizare și Asociere să se concentreze mai mult pe aspectele politice ale reformelor efectuate, în timp ce Conferințelor Interguvernamentale ar trebui să le revină sarcina de a furniza sprijinul politic necesar, la cel mai înalt nivel, pentru direcționarea adecvată a procesului de negociere ${ }^{21}$.

La nivel practic, aceste propuneri se referă, spre exemplu, la includerea reprezentanților statelor candidate în angajamentele la nivel guvernamental sau superior, în toate proiectele, programele sau parteneriatele care includ statele candidate. Este oferit, în acest sens, exemplul programului Orizont 2020, în sensul în care atunci când aspecte precum desfăşurarea viitoare sau oportunitatea acestuia figurează pe ordinea de zi a Consiliului, reprezentanţii statelor candidate ar trebui invitați să ia parte la dezbateri, pentru a lua contact cu ceea ce presupune calitatea de stat membru, din punctul de vedere al drepturilor care însoțesc această calitate, obligațiilor asumate și nu numai ${ }^{22}$.

Un alt element al conceptului de control politic se referă la necesitatea sau oportunitatea includerii Statelor Membre în monitorizarea progreselor efectuate de statele candidate în cadrul procesului de aderare, printr-o utilizare îmbunătățită a instituțiilor din cadrul acordurilor de asociere (cum ar fi Consiliile de Asociere ${ }^{23}$, Comitetele de Asociere ${ }^{24}$ sau Comisiile Parlamentare Comune) prin intermediul cărora ar trebui să se poată realiza un dialog real asupra parcursului procesului de negociere, dar și asupra a ceea ce rămâne de efectuat $^{25}$.

De asemenea, Statele Membre vor fi, conform propunerii Comisiei, invitate să contribuie sistematic la desfășurarea procesului de aderare, inclusiv prin acțiuni de monitorizare în teren desfășurate de experți naționali, contribuții directe la întocmirea rapoartelor anuale și prin intermediul expertizei furnizate în sectoare determinate.

În continuare, în cadrul procesului de negociere, vor avea loc Conferințe Interguvernamentale pentru fiecare stat canditat în parte, după publicarea pachetului anual de rapoarte privitoare la statele candidate, menite a reprezenta un forum de dialog politic privitor la reforme, stadiul general al procesului de negociere și planificarea direcțiilor acestuia pentru anul următor, inclusiv aspecte legate de deschiderea sau închiderea de capitole/clustere de capitole, respectiv posibile măsuri coercitive. În cadrul acestor Conferințe vor fi reprezentate toate părțile implicate, la nivelul necesar unui dialog politic eficient.

În ceea ce privește Consiliile de Stabilizare și Asociere, acestea vor furniza, de asemenea, un impuls suplimentar necesar și complementar pentru dialogul politic asupra reformelor. De asemenea, ele pot, împreună cu Comitetele de Stabilizare și Asociere și sub-

\footnotetext{
${ }^{21}$ Communication from the Commission to the Euroepan Parliament, the Council, the Euroepan Economic and Social Committee and the Committee of the Regions: Enhancing the accession process - A credible EU perspective for the Western Balkans, COM(2020) 57 final, Brussels, 5.2.2020.

22 *** Remarks by Commissioner Olivér Várhelyi at the press conference on the revised enlargement methodology, 05.02.2020, accesat 24.05.2020.

${ }^{23}$ Spre exemplu, Articolul 435 din Acordul de Asociere între Republica Moldova, pe de o parte, și Uniunea Europeană și Comunitatea Europeană a Energiei Atomice și statele membre ale acestora, pe de altă parte, are următorul cuprins ce consacră o astfel de instituție: (1) Consiliul de asociere este compus din membri ai Consiliului Uniunii Europene și ai Comisiei Europene, pe de o parte, și din membri ai Guvernului Republicii Moldova, pe de altă parte. (2) Consiliul de asociere își stabilește propriul regulament de procedură. (3) Consiliul de asociere este prezidat, alternativ, de un reprezentant al Uniunii și de un reprezentant al Republicii Moldova. (4) După caz și prin acord reciproc, la lucrările Consiliului de asociere pot lua parte reprezentanți ai altor organisme, ca observatori.

${ }^{24}$ Articolul 437 din același Acord: (1) Se instituie Comitetul de asociere. Acesta asistă Consiliul de asociere în îndeplinirea sarcinilor sale. (2) Comitetul de asociere este compus din reprezentanți ai părților, în principiu, la nivel de înalți funcționari. (3) Comitetul de asociere este prezidat, alternativ, de un reprezentant al Uniunii și de un reprezentant al Republicii Moldova.

25 *** Remarks by Commissioner Olivér Várhelyi at the press conference on the revised enlargement methodology, 05.02.2020, accesat 24.05.2020.
} 
comitelele acestora, să furnizeze cadrul pentru o mai eficientă monitorizare a procesului de aderare sau să gestioneze aspectele legate de accelerarea integrării în cadrul diferitelor clustere tematice.

Și, pentru că am făcut referire la noțiunea de clustere tematice fără a o detalia, a sosit momentul să facem și acest lucru.

Astfel, în viziunea Comisiei, gruparea capitolelor de negociere în clustere adaugă un element suplimentar de dinamism procesului de negociere, prin faptul că aduce împreună capitolele în funcție de specificul acestora. Astfel, se vor forma șase grupuri de capitole ${ }^{26}$ : aspecte fundamentale, piața internă, competitivitate și dezvoltare incluzivă, agenda verde și conectivitate sustenabilă; resurse, agricultură și coeziune, respectiv relații externe. În cadrul fiecărui asemenea grup, negocierile vor fi demarate în întregul său, după îndeplinirea tuturor reperelor fundamentale, în locul abordării individuale a capitolelor, de până acum. De asemenea, intervalul de timp dintre deschiderea unui grup de capitole și închiderea capitolelor individuale ar trebui să fie limitat, spre exemplu, la un an, depinzând și de desfășurarea generală a procesului de reformă ${ }^{27}$.

Gruparea capitolelor aduce și un sprijin suplimentar pentru îndeplinirea criteriilor juridice, ceea ce înseamnă că deschiderea negocierilor de aderare se va produce cu clusterul privitor la statul de drept și se va încheia tot cu acesta, metodă prin care Comisia dorește să se asigure că elementele din cadrul acestui cluster vor fi monitorizate în permanență și li se va acorda o continuă atenție de către statul candidat, de-a lungul întregului proces ${ }^{28}$.

În viziunea Comisiei, gruparea capitolelor va permite un accens suplimentar asupra chestiunilor cheie din cadrul dialogului politic și va oferi un cadru mai eficient pentru creșterea gradului de angajament politic (din partea statelor candidate). De asemenea, un alt merit al acestei reforme, în viziunea aceleiași Comisii, este acela de a permite identificarea celor mai importante și mai urgente reforme din fiecare sector, ceea ce va conferi procesului general de reformă din statele candidate un impuls suplimentar, prin plasarea accentului asupra acelor reforme sectoriale care corespund cel mai bine atât intereselor cetățenilor, cât și celor ale mediului de afaceri.

Așadar, după cum spuneam, procesul de negociere din cadrul fiecărui grup de capitole va demara ca întreg, și nu în mod individual. În urma procesului de evaluare (screening) desfășurat la nivelul capitolelor care alcătuiesc un cluster, Uniunea și statul candidat vor ajunge la un acord în privința aspectelor prioritare care necesită o accelerare a integrării și efectuarea unor reforme cheie. După efectuarea reformelor necesare de către statul candidat, negocierea în cadrul grupurilor date de capitole va fi demarată fără alte condiții, cu stabilirea unor ținte de atins în vederea închiderii fiecărui capitol. În cazul în care statul candidat a efectuat deja reforme importante înaintea deschiderii negocierilor, intervalul de timp dintre deschiderea negocierilor la nivel de cluster și închiderea capitolelor indivituale poate fi unul redus, de preferat mai puțin de un an, dar acest lucru depinde de progresul reformelor așteptate.

Fiecare cluster va fi gestionat de o serie de subcomitete din cadrul mecanismelor prevăzute de Acordurile de Stabilitate și Asociere, astfel încât progresul din cadrul fiecărui cluster să poată fi monitorizat și să poată fi adoptate cu celeritate măsuri de aliniere în cadrul

\footnotetext{
26 *** Remarks by Commissioner Olivér Várhelyi at the press conference on the revised enlargement methodology, 05.02.2020, accesat 24.05.2020.

${ }^{27}$ Communication from the Commission to the Euroepan Parliament, the Council, the Euroepan Economic and Social Committee and the Committee of the Regions: Enhancing the accession process - A credible EU perspective for the Western Balkans, COM(2020) 57 final, Brussels, 5.2.2020.

28 *** Remarks by Commissioner Olivér Várhelyi at the press conference on the revised enlargement methodology, 05.02.2020, accesat 24.05.2020.
} 
oferit de structurile prevăzute de Acorduri. Prin acest mecanism, Comisia se așteaptă să poată desfășura sesiuni punctuale de dialog privitoare la aspecte concrete, în urma cărora să fie identificate oportunități de aliniere și integrare accelerată, în toate domeniile de politici unionale, ceea ce ar aduce beneficii ambelor părți.

Ajungem, în final, la poate cel mai important aspect al acestei reforme, și anume, principiul predictibilității.

Aceasta se referă, în viziunea Comisarului Várhelyi la faptul că Uniunea trebuie să stabilească, pentru statele candidate, o serie de condiții clar definite, astfel încât ambele părți să știe ce se cere și ce poate fi obținut în cadrul acestui proces. Acesta este și motivul pentru care Comisia dorește să implice Statele Membre în monitorizarea progresului negocierilor și pentru care afirmă necesitatea ca statele să partajeze cu instituția Comisiei rezultatele analizelor efectuate, pentru a se putea evita orice surprize ${ }^{29}$ asemănătoare celei la care am asistat cu toții de curând.

De asemenea, predictibilitatea procesului de negociere a aderării implică și faptul că instituția Comisiei trebuie să indice mai clar ce așteaptă Uniunea de la statele candidate în fiecare etapă a procesului de negociere, că sunt clarificate consecințele pozitive pe care le pot aduce reformele și care pot fi consecințele negative ale neefecturării progreselor așteptate ${ }^{30}$.

Astfel, pentru a încuraja efectuarea unor reforme despre a căror dificultate are o deplină cunoștință, Comisia va defini mai exact condițiile pe care statele candidate trebuie să le îndeplinească și va oferi recompense clare și tangibile, în interesul direct al cetățenilor acelor state. Acestea pot include accelerarea negocierilor de aderare, implementarea anticipată, în etape, a unor politici unionale ori a accesului pe piața internă a Uniunii sau la diferitele programe ale acesteia, concomitent cu asigurarea unui tratament echitabil pentru statele candidate, precum și creșteri ale alocărilor de fonduri sau ale investițiilor. Cu cât statele candidate vor avansa mai mult pe calea acestor reforme, cu atât mai mult vor beneficia de instrumentele menționate. De asemenea, Comisia propune și adoptarea unor măsuri mai decisive pentru sancționarea proporțională a oricărei stagnări serioase sau prelungite ori a orcărei inversări a procesului de reformă implicat de necesitatea de a îndeplini criteriile implicate de procesul de aderare. În această idee, Comisia admite și posibilitatea suspendării temporare a negocierilor în anumite domenii sau, în cazurile cele mai grave, suspendarea totală a procesului de negociere ori redeschiderea capitolelor închise, suspendarea beneficiilor deja acordate sau a accesului la programe, finanțare etc ${ }^{31}$.

Comisia consideră condiționalitatea ca fiind elementul cheie al abordării bazate pe merit. Dar pentru ca acesta să-și releve întreaga valoare este nevoie de stabilirea cu maximă claritate, de la început, a condițiilor necesar de îndeplinit. $\mathrm{Cu}$ alte cuvinte, este important ca statele candidate să cunoască reperele în funcție de care este evaluată performanța lor și ca Statele Membre să împărtășească, la rândul lor, o viziune comună cu privire la ce criterii trebuie să îndeplinească un stat candidat pentru a dobândi statutul de membru. Pentru atingerea acestor deziderate, Comisia va defini mai clar condițiile ale căror îndeplinire, de către statele candidate, conduce la progrese ale procesului de negociere, în principal prin intermediul rapoartelor anuale. Condițiile în cauză trebuie să prezinte un caracter obiectiv, precis, detaliat, strict și verificabil. Comisia urmează a utiliza și raportări efectuate de terți

\footnotetext{
29 *** Remarks by Commissioner Olivér Várhelyi at the press conference on the revised enlargement methodology, 05.02.2020, accesat 24.05.2020.

${ }^{30}$ Communication from the Commission to the Euroepan Parliament, the Council, the Euroepan Economic and Social Committee and the Committee of the Regions: Enhancing the accession process - A credible EU perspective for the Western Balkans, COM(2020) 57 final, Brussels, 5.2.2020.

${ }^{31}$ Communication from the Commission to the Euroepan Parliament, the Council, the Euroepan Economic and Social Committee and the Committee of the Regions: Enhancing the accession process - A credible EU perspective for the Western Balkans, COM(2020) 57 final, Brussels, 5.2.2020.
} 
pentru a le furniza Statelor Membre o bază cât mai largă de informații pe baza cărora să își structureze conduita.

Prin furnizarea unor stimulente clare și tangibile, de interes direct pentru cetățeni, Uniunea poate încuraja formarea voinței politice reale în sensul efectării reformelor necesare aderării, în statele membre, și poate recompensa obținerea de rezultate în urma procesului de reformă despre care cunoaştem din proprie experiență că pot fi anevoioase, în direcția unor autentice schimbări de natură economică sau societală. Mai exact, în cazul în care reformele prioritare convenite în cadrul negocierilor sunt efectuate, UE va consimți la o adâncire a intergării respectivului stat, pe sectoare, astfel cum am explicat mai sus.

Pe de altă parte, unul dintre imperativele pe care le subliniază Comisia, pe baza experiențelor anterioare de negociere cu statele candidate, este acela al reversării procesului de negociere, atunci când statele candidate nu avansează pe calea reformelor sau chiar le inversează în tot sau în parte ${ }^{32}$.

Din ceea ce Comisia consideră a reprezenta pregătirea statelor candidate din Balcanii de Vest pentru dobândirea calității de stat membru, cu toate drepturile și obligațiile care decurg din aceasta, o importantă parte o reprezintă reformele fundamentale în domeniile caracterului democratic al statului, domniei legii, economiei și respectării valorilor pe care se întemeiază Uniunea. Comisia este de părere că efectuarea acestor reforme sta la baza unei accelerate dezvoltări economice și atingerii convergenței sociale.

Un rol important în eficientizarea procesului de aderare este reprezentat de comunicarea strategică. În întreaga regiune a Balcanilor de Vest, este esențial ca avantajele, oportunităţile integrării și natura și efectele reformelor necesar a fi efectuată să fie evidențiate. Totodată, este cel puțin la fel de necesară combaterea influenței nocive ale statelor terțe care sprijină tendințele eurosceptice. Dar toate acestea implică nu doar eforturi din partea Uniunii, ci și din cea a statelor candidate. Implicarea autorităților acestora în realizarea obiectivului integrării va fi, pe viitor, tratată cu mai multe atenție în rapoartele anuale ale Comisiei.

$\mathrm{Nu}$ în ultimul rând, principiile predictibilității și condiționalității sunt sprijinite în aplicarea lor prin aprofundarea transparenței, cu implicarea tuturor actorilor cheie și printr-o mai completă publicare a documentelor implicate, de către Comisie.

Tot Comisiei îi revine sarcina de a-și continua activitatea de comunicare și informare, inclusiv prin reprezentanțele acesteia în statele membre, deși responsabilitatea principală de informare a cetățenilor, în special cu privire la oportunitățile strategice și provocările procesului de aderare a noilor state revine în principal statelor membre.

Următoarea etapă în parcursul Comunicării Comisiei privitoare la procedura revizuită a aderării noilor state a constat în dezbaterea acesteia în Parlamentul European, ca una dintre „,instituțiile care au cea mai consistentă legitimitate democratică (...) [alături de Consiliul European], dată de apropierea existentă între votul cetățeanului european și persoanele care, in mod evident, compun aceste instituții" ${ }^{33}$, dezbatere ce a avut loc în data de 10 februarie 2020.

În continuare, Consiliul Afaceri Externe din martie 2020 a luat cunoștință de cuprinsul Comunicării Comisiei privitoare la revizuirea metodologiei de negociere a aderării noilor state, în aceeași reuniune în care a decis și deschiderea negocierilor de aderare cu Macedonia de Nord, pe baza acestei metodologii revizuite, ceea ce poate fi considerat drept o îndeplinire a ambelor obiective ale Comisiei, respectiv edificarea unei noi metodologii de aderare și deblocarea impasului în care intrase parcursul european al statelor amintite.

\footnotetext{
32 *** Remarks by Commissioner Olivér Várhelyi at the press conference on the revised enlargement methodology, 05.02.2020, accesat 24.05.2020.

${ }^{33}$ Augustin Fuerea, Legislativul Uniunii Europene între unicameralism și bicameralism, în Revista Dreptul, nr. 7/2017, pp. 188-200.
} 
În aceeași idee, Concluziile Reuniunii Consiliului European de la Zagreb, din 6 mai 2020, desfășurată online din cauza pandemiei de COVID-19, subliniază faptul că, ,în vederea promovării în continuare a intereselor noastre comune, liderii UE își exprimă disponibilitatea de a revigora dialogul politic, inclusiv în mod sistematic la nivel inalt, dintre UE și Balcanii de Vest [și salută] (...) faptul că partenerii noștri din Balcanii de Vest se aliniază la punctele sus-menționate" ${ }^{34}$.

În concluzie, suntem de părere că desfășurarea evenimentelor care au dus la elaborarea acestei noi metodologii privitoare la aderarea noilor state la Uniunea Europeană confirmă, pe de o parte, cele afirmate de doctrina de specialitate și reafirmate în debutul acestei succinte prezentări, respectiv ideea că Uniunea nu doar că supraviețuiește, ci și evoluează cu fiecare criză prin care trece, exact datorită acestor crize și a reflecțiilor pe care le prilejuiesc, ceea ce nu conduce la slăbirea rezistenței (în sensul de resilience) edificiului unional, ci tocmai la întărirea acestuia și, pe de altă parte, cele afirmate în repetate rânduri de doctrina de specialitate din domeniul relaţiilor internaționale, conform căreia o abordare bazată pe merite este cel mai eficient instrument de negociere în relațiile cu statele de la care se așteaptă efectuarea unor reforme, sub condițiile (cumulative) ca negocierile să se desfășoare într-o atmosferă predictibilă, în care consecințele conformării sunt stabilite cu claritate și oferite în mod corespunzător, iar cele ale neconformării sunt reprezentate de sancțiuni proporționale aplicate cu promptitudine. Ceea ce, de altfel, constituie esența abordării prezentate de Comisie în documentul analizat.

Materialul a fost publicat în revista online a Facultăţii de Drept, $\underline{\text { AUBD - Forum Juridic }}$ nr. 2/2020.

\section{BIBLIOGRAFIE}

1. Baczynska, Gabriela, France opposes EU membership talks with North Macedonia, Albania: diplomats, www.reuters.com, 10.10.2019, accesat 24.05.2020.

2. Dumitrașcu, Augustina; Popescu, Roxana-Mariana, Dreptul Uniunii Europene: sinteze și aplicații, ediția a II-a revăzută și adăugită, Editura Universul Juridic, București, 2015, pp. 173-175.

3. Fuerea, Augustin, Manualul Uniunii Europene, Ediția a V-a revăzută și adăugită după Tratatul de la Lisabona, Editura Universul Juridic, București, 2011.

4. Fuerea, Augustin, Legislativul Uniunii Europene între unicameralism și bicameralism, în Revista Dreptul, nr. 7/2017, pp. 188-200.

5. Salomia, Oana-Mihaela; Mihalache, Augustin, Principiul egalității statelor membre în cadrul Uniunii Europene, Revista "Dreptul”, nr. 1/2016, pp. 166-174.

6. *** Remarks by Commissioner Olivér Várhelyi at the press conference on the revised enlargement methodology, 05.02.2020.

7. Communication from the Commission to the Euroepan Parliament, the Council, the Euroepan Economic and Social Committee and the Committee of the Regions: Enhancing the accession process - A credible EU perspective for the Western Balkans, COM(2020) 57 final, Brussels, 5.2.2020.

8. *** North Macedonia, ec.europa.eu, 15.04.2020, accesat 24.05.2020.

9. ***Zagreb Declaration, 6 May 2020, www.consilium.europa.eu, 06.05.2020.

$34 * * *$ Zagreb Declaration, 6 May 2020, www.consilium.europa.eu, 06.05.2020, accesat 24.05.2020. 